\title{
GAMBARAN TUMBUH KEMBANG ANAK BAWAH DUA TAHUN (BADUTA) YANG MEMILIKI IBU BEKERJA ATAU TIDAK BEKERJA DI KELURAHAN BENDOGERIT KECAMATAN SANANWETAN KOTA BLITAR (The Description of Growth and Development Under Two Years Children Who Have a Working Mother or Not Working)
}

\author{
Qurrotu 'Ainii \\ Program Studi D-3 Keperawatan Blitar \\ Politeknik Kesehatan Kementrian Kesehatan Malang \\ email: qurrotu@gmail.com
}

\begin{abstract}
In a child's life there are two processes that continue operating in growth and development, this process takes place interdependency which depend on each other.Experts say infant is a golden period, especially the age of 0-2 years old to reach $80 \%$ of the brain development. Lack affection of mother-first year of life have a negative impact on the upbringing of children. The purpose of this study was to determine the picture of the development-growing children under 2 years old who have working mothers or not working at the Village Bendogerit Sananwetan District of Blitar. Method:This study was a descriptive study. The samples were taken with quota sampling technique using pre-screening questionnaire instrument development and anthropometric assessment. Result : From the research, the growth of children under 2 years old with the mother does not work 100\% had appropriate growth and growth of children under 2 years old $93.75 \%$ of working mothers have the appropriate growth. While the development of the child under 2 years old with the mother does not work $93.75 \%$ had appropriate growth and development of children under 2 years old $87.5 \%$ of working mothers have the appropriate development. Discussion: Thus, the conclusion drawn growing up baduta in Village Bendogerit, Sananwetan District of Blitar with the mother did not work better than the development of the child baduta with working mothers. In accordance with the conclusions that had been raised, researchers gave suggestions to further research to better focus on the factors that affect growth and development in the mother works, as well as advice for the child's mother always bring KMS and always filled by officers.
\end{abstract}

Keywords: growth, development, children under two years old, mother, working, not working

\begin{abstract}
Abstrak: Dalam kehidupan seorang anak ada dua proses yang terus beroperasi dalam pertumbuhan dan perkembangan, proses ini berlangsung interdepedentcy yang bergantung satu sama lain, para ahli mengatakan bayi merupakan masa emas, terutama usia 0-2 tahun untuk mencapai $80 \%$ dari otak pengembangan. Kurangnya kasih sayang tahun ibu-pertama kehidupan memiliki dampak negatif pada pendidikan anakanak. Tujuan dari penelitian ini adalah untuk mengetahui gambaran perkembangan anak yang tumbuh di bawah 2 tahun yang ibunya bekerja atau tidak bekerja di Sananwetan Desa Bendogerit Blitar. Metode: Penelitian ini merupakan penelitian deskriptif. Sampel diambil dengan teknik quota sampling menggunakan pre-screening pengembangan instrumen kuesioner dan penilaian antropometri. Hasil: Dari penelitian, pertumbuhan anak di bawah 2 tahun dengan ibu tidak bekerja $100 \%$ memiliki pertumbuhan yang tepat dan pertumbuhan anak di bawah 2 tahun $93,75 \%$ dari ibu yang bekerja memiliki pertumbuhan yang sesuai. Sementara perkembangan anak berusia di bawah dengan ibu 2 tahun tidak bekerja 93,75\% memiliki pertumbuhan yang tepat dan perkembangan anak di bawah 2 tahun $87,5 \%$ dari ibu yang bekerja memiliki pembangunan yang tepat. Diskusi: Dengan demikian, kesimpulan yang ditarik tumbuh baduta di Desa
\end{abstract}


Bendogerit, Sananwetan Kabupaten Blitar dengan ibu tidak bekerja lebih baik daripada perkembangan baduta anak dengan ibu yang bekerja. Sesuai dengan kesimpulan yang telah dikemukakan, peneliti memberikan saran untuk penelitian lebih lanjut untuk lebih fokus pada faktor-faktor yang mempengaruhi pertumbuhan dan perkembangan pada ibu bekerja, serta saran bagi ibu anak selalu membawa KMS dan selalu diisi oleh petugas.

Kata Kunci: pertumbuhan, perkembangan, anak di bawah dua tahun, ibu, bekerja, tidak bekerja

Dalam kehidupan anak ada dua proses yang beroperasi secara continue yakni pertumbuhan dan perkembangan, kedua proses ini berlangsung secara interdepedensi yakni saling bergantung satu sama lainnya. Pertumbuhan berkaitan dengan perubahan kuantitaif yang menyangkut peningkatan ukuran dan struktur biologis sedangkan perkembangan merupakan suatu proses yang menggambarkan perilaku kehidupan sosial psikologi manusia pada posisi yang harmonis didalam lingkungan masyarakat yang lebih luas dan kompleks (Hidayat, 2005).

Istilah tumbuh kembang mencakup dua peristiwa yang sifatnya berbeda, tetapi saling berkaitan dan sulit dipisahkan yaitu pertumbuhan dan perkembangan. Sedangkan pengertian dari pertumbuhan adalah berkaitan dengan masalah perubahan dalam besar, jumlah ukuran, atau dimensi tingkat sel, organ maupun individu, yang bisa diukur dengan berat (gram, pound, kilogram), ukuran panjang (sentimeter, meter) umur tulang dan keseimbangan metabolik (retensi natrium dan nitrogen tubuh). Perkembangan adalah bertambahnya kemampuan (skill) dalam struktur dan fungsi tubuh yang lebih kompleks dalam pola yang teratur dan dapat di deferensisasikan dari sel-sel tubuh, jaringan tubuh, organ-organ dan sistem organ yang berkembang sedemikian rupa sehingga masing-masing dapat memenuhi fungsinya termasuk juga perkembangan emosi, intelektual dan tingkah laku sebagai hasil interaksi dengan lingkungannya (Soetjiningsih, 1995).

Masa di bawah usia lima tahun (balita) merupakan periode paling kritis dalam menentukan kualitas sumber daya manusia, pada lima tahun pertama proses tumbuh kembang berjalan dengan cepat, para ahli mengatakan bahwa masa balita tersebut sebagai masa emas ("golden age period") khususnya pada usia 0-2 tahun perkembangan otak mencapai $80 \%$, apabila pada masa tersebut anak balita tidak dibina secara baik, maka anak tersebut akan mengalami gangguan perkembangan baik emosi, sosial, mental, intelektual dan moral yang akan sangat menentukan sikap serta nilai pola perilaku seseorang dikemudian hari (Wahyuni, 2013).
Dalam tumbuh kembang anak tidak sedikit peranan ibu dalam ekologi anak yaitu peran ibu sebagai "para genetik faktor" yaitu pengaruh biologisnya terhadap pertumbuhan janin dan pengaruh psikobiologinya terhadap pertumbuhan post natal dan perkembangan kepribadian (Soetjiningsih, 1995). Semakin meningkat jumlah ibu bekerja (terutama di kota besar), semakin kompleks pula dinamika kehidupan seperti tuntutan finansial dan biaya pendidikan anak. Para ibu menjadi pekerja keras untuk dapat membantu memenuhi kebutuhan hidup keluarganya. Padahal, menurut teori kebutuhan dasar anak Titi dalam Soetjiningsih 1995 secara umum digolongkan menjadi 3 kebutuhan dasar yaitu asuh, asih, dan asah, dalam teori Asih yaitu kebutuhan emosi atau kasih sayang pada tahun-tahun pertama kehidupan, hubungan yang erat, mesra dan selaras antara ibu dengan anak merupakan syarat mutlak untuk menjamin tumbuh kembang yang selaras baik fisik, mental maupun psikososial. Berperannya dan kehadiran ibu sedini dan selanggeng mungkin akan menjalin rasa aman bagi bayinya. Ini di wujudkan dengan kontak fisik (kulit, mata) dan psikis sedini mungkin, misalnya dengan menyusu bayi secepat mungkin segera setelah lahir. Kekurangan kasih sayang ibu pada tahun-pertama kehidupan mempunyai dampak negatif pada tumbuh kembang anak baik fisik, mental maupun sosial emosi, yang disebut "Sindrom Deprivasi Mental"

Berdasarkan penelitian dari "The Institute of Science and Technology Journal's" menunjukkan bahwa perempuan Indonesia telah bekerja saat berusia 22 tahun (belum menikah). Hanya sebagian kecil dari mereka yang berhenti bekerja setelah menikah dan memiliki anak. Selain itu, di Indonesia terdapat lebih dari $40 \%$ perempuan menjalankan fungsi ganda, yaitu membesarkan anak sambil bekerja. Institute for Social and Economic Research dari Essex University juga mengadakan penelitian. Ibu yang kembali bekerja pada tiga tahun pertama pertumbuhan anak berdampak pada pertumbuhan anak yang lamban bahkan, studi yang digelar Unicef pada 2008 merekomendasikan, sebaiknya ibu tetap 
berada di rumah pasca melahirkan, hingga satu tahun. Hal ini menunjukkan bahwa aktifitas ibu sangat berpengaruh terhadap pertumbuhan anak (Wardah, 2010).

Hasil wawancara pada 6 orang ibu bekerja dan 6 orang ibu yang tidak bekerja didapatkan pada penilaian perkembangan menggunakan denver salah satu ibu yang bekerja mempunyai anak 7 bulan yang seharusnya sudah dapat menopang dada saat tengkurap ternyata belum dapat melakukan sedangkan anak yang berumur 8 bulan dengan ibu yang bekerja berat badan anak tersebut berada di bawah garis merah pada grafik berat badan KMS.

Berdasarkan data dan kondisi yang dikemukakan diatas yaitu gambaran keterlambatan tumbuh kembang anak pada ibu bekerja dan tidak bekerja, maka peneliti tertarik untuk mengetahui gambaran tumbuh kembang anak baduta yang memiliki ibu bekerja atau tidak bekerja di Kelurahan Bendogerit Kota Blitar.

Tujuan penelitian ini adalah mengetahui gambaran tumbuh-kembang anak baduta yang memiliki ibu bekerja, tidak bekerja di Kelurahan Bendogerit Kecamatan Sananwetan Kota Blitar.

\section{BAHAN DAN METODE}

Desain dalam penelitian ini adalah penelitian deskriptif. Penelitian deskriptif ialah bertujuan untuk mendeskripsikan (memaparkan) peristiwa-peristiwa urgen yang terjadi pada masa kini (Nursalam, 2003).

Penelitian ini menggambarkan tumbuh kembang baduta yang mempunyai ibu bekerja atau tidak bekerja di Kelurahan Bendogerit, Kecamatan Sananwetan, Kota Blitar.

Sampel diambil dengan teknik quota sampling menggunakan instrumen kuisioner pra-skrining perkembangan, penilaian antropometri. Pada penelitian ini populasi yang digunakan adalah seluruh baduta se Kelurahan Bendogerit yang terdaftar di posyandu sebanyak 217 baduta.

Dalam penelitian ini sampel yang diperlukan sebanyak 32 baduta, terdiri dari baduta yang memiliki ibu bekerja sebanyak 16 dan ibu tidak bekerja sebanyak 16 orang. Adapun kriteria inklusi sampel yaitu anak baduta dengan ibu bekerja atau tidak bekerja yang tinggal satu rumah dengan ibunya.

Pengambilan data dilaksanakan di posyandu di Kelurahan Bendogerit Kecamatan Sanan Wetan, Kota Blitar dan di laksanakan pada bulan April 2015.
Variabel dalam penelitian ini adalah pertumbuhan dan perkembangan baduta yang memiliki ibu bekerja dan tidak bekerja.

Pada penelitian ini analisa data akan ditampilkan dalam bentuk interpretasi KPSP dalam penilaian perkembangan baduta adalah dengan menghitung berapa jumlah jawaban "ya". Jawaban "ya" bila ibu menjawab: anak bisa, atau pernah atau sering atau kadang kadang melakukannya. Jawaban "tidak" bila ibu menjawab anak belum pernah melakukan atau tidak pernah atau tidak tahu. Jika jumlah "ya" 9 atau 10 perkembangan anak sesuai dengan tahap perkembanganya (S), jika jawaban "ya" 6, 7 atau 8 perkembangan anak meragukan (M), jika jawaban "ya" 5 atau kurang, kemungkinan ada penyimpangan (P). Untuk jawaban tidak perlu dirinci jumlah jawaban "tidak" menurut jenis keterlambatan pada sektor yang mana. Sedangkan pada interpretasi penilaian antropometri adalah penilaian pada berat badan dan tinggi badan dengan melihat kolom pada tabel berat badan/tinggi badan direktorat gizi masyarakat 2002. Sedangkan ukuran lingkar kepala interpretasinya: bila ukuran lingkar kepala anak berada dalam "jalur hijau" maka lingkaran kepala anak normal, bila ukuran lingkaran kepala anak berada di luar "jalur hijau" maka lingkaran kepala anak tidak normal yaitu makrosefal jika berada di atas "jalur hijau" dan mikrosefal bila berada di bawah "jalur hijau". Kemudian hasil pengolahan data diintrperstasikan kedalam skala kuantitatif dalam bentuk tabel untuk dianalisa secara deskriptif.

\section{HASIL PENELITIAN}

\section{Data Umum}

Data umum menyajikan tentang karakteristik responen berdasarkan umur, jenis kelamin, dan pekerjaan ibu.

Berdasarkan tabel 1 didapatkan bahwa umur yang paling banyak dari anak baduta adalah kisaran umur 10-12 bulan dengan jumlah 21,9\% atau 7 anak dan jumlah umur paling kecil adalah umur anak baduta $16-18$ bulan dengan jumlah $3,1 \%$ atau 1 anak baduta, dan umur 22-24 bulan berjumlah 3,1\% atau 1 anak baduta.

Berdasarkan tabel 2 didapatkan bahwa jenis kelamin yang paling banyak adalah perempuan dengan jumlah 53,1\% atau 17 anak baduta. 
Tabel 1. Umur anak baduta di Posyandu Kelurahan Bendogerit Kecamatan Sananwetan Kota Blitar pada bulan April tahun $2015(\mathrm{n}=32)$

\begin{tabular}{ccc}
\hline Umur & Frek & \% \\
\hline 0-3 bulan & 6 & 18,8 \\
4-6 bulan & 3 & 9,4 \\
7-9 bulan & 5 & 15,6 \\
10-12 bulan & 7 & 21,9 \\
$13-15$ bulan & 6 & 18,8 \\
$16-18$ bulan & 1 & 3,1 \\
$19-21$ bulan & 3 & 9,4 \\
22-24 bulan & 1 & 3,1 \\
\hline Jumlah & 32 & 100 \\
\hline
\end{tabular}

Tabel 2. Jenis kelamin anak baduta di Posyandu Kelurahan Bendogerit Kecamatan Sanwetan Kota Blitar pada bulan April, 2015 (n=32)

\begin{tabular}{ccc}
\hline $\begin{array}{c}\text { Jenis } \\
\text { kelamin }\end{array}$ & Frekuensi & Prosentase \\
\hline Laki laki & 15 & $46,9 \%$ \\
Perempuan & 17 & $53,1 \%$ \\
\hline Jumlah & 32 & $100 \%$ \\
\hline
\end{tabular}

\section{Data Khusus}

Data khusus menyajikan tantang pertumbuhan dan perkembangan anak baduta pada ibu bekerja dan tidak bekerja di Posyandu Balita se-Kelurahan Bendogerit Kota Blitar pada bulan April 2015.
Berdasarkan tabel 3 didapatkan bahwa pertumbuhan responden pada ibu tidak bekerja sejumlah 16 anak memiliki pertumbuhan yang sesuai atau normal, sedangkan pertumbuhan responden pada ibu bekerja sejumlah $93,75 \%$ atau 15 anak baduta memiliki pertumbuhan yang sesuai atau normal dan $6,25 \%$ atau 1 anak baduta memiliki pertumbuhan yang tidak sesuai atau tidak normal dan dapat menyebabkan obesitas. Selain itu pemenuhan kebutuhan pokok pada tahap awal perkembangan balita seperti pemberian ASI, imunisasi, pemenuhan sandang, dan kesegaran jasmani rekreasi dapat mempengaruhi proses tumbuh kembang pada anak.

Berdasarkan tabel 4 didapatkan data bahwa pada ibu yang tidak bekerja hanya ada $3,1 \%$ atau 1 anak baduta yang memiliki perkembangan meragukan sedangkan pada ibu bekerja terdapat $3,1 \%$ atau 1 anak baduta yang memiliki perkembangan meragukan dan 3,1\% atau 1 anak baduta memiliki perkembangan yang menyimpang dari usianya

\section{PEMBAHASAN}

Berdasarkan hasil penelitian, diperoleh pertumbuhan anak baduta dengan ibu bekerja $100 \%$ memiliki pertumbuhan normal, sedangkan pertumbuhan anak baduta dengan ibu bekerja $93,75 \%$ memiliki pertumbuhan yang sesuai, dan 1 anak baduta berumur 15 bulan dengan ibu bekerja memiliki berat badan dan tinggi badan tidak sesuai yang seharusnya anak tersebut memiliki berat badan $6,9-11,5 \mathrm{~kg}$ tetapi, anak tersebut memilki berat badan $8,7 \mathrm{~kg}$ sehingga anak tersebut memiliki perktumbuhan yang tidak sesuai.

Tabel 3. Kategori pertumbuhan anak baduta berdasarkan pekerjaan ibu di Posyandu Kelurahan Bendogerit kecamatan Sananwetan Kota Blitar pada bulan April $2015(n=32)$

\begin{tabular}{cccccccc}
\hline \multirow{2}{*}{ Pertumbuhan } & \multicolumn{4}{c}{ Pekerjaan Ibu } & \multicolumn{2}{c}{ Jumlah } \\
\cline { 2 - 6 } & \multicolumn{2}{c}{ Tidak Bekerja } & \multicolumn{2}{c}{ Beker ja } & \multirow{2}{*}{ f } & \% \\
\cline { 2 - 6 } & $\mathbf{f}$ & $\mathbf{\%}$ & $\mathbf{f}$ & $\mathbf{\%}$ & f & \\
\hline Normal & 16 & 50 & 15 & 46,9 & 31 & 96,9 \\
Tidak normal & 0 & 0 & 1 & 3,1 & 1 & 3,1 \\
\hline Jumlah & 16 & 50 & 16 & 50 & 32 & 100 \\
\hline
\end{tabular}

Tabel 4. Kategori perkembangan anak baduta berdasarkan pekerjaan ibu di Posyandu Kelurahan Bendogerit kecamatan Sananwetan Kota Blitar pada bulan April $2015(\mathrm{n}=32)$

\begin{tabular}{lccccccc}
\hline \multirow{3}{*}{ Perkembangan } & \multicolumn{4}{c}{ Pekerjaan Ibu } & \multicolumn{1}{c}{ Jumlah } \\
\cline { 2 - 6 } & \multicolumn{2}{c}{ Tidak Bekerja } & Bekerja & & \multirow{2}{*}{ f } \\
\cline { 2 - 6 } & $\mathbf{f}$ & $\boldsymbol{\%}$ & $\mathbf{f}$ & $\boldsymbol{\%}$ & $\mathbf{f}$ & $\boldsymbol{\%}$ \\
\hline Sesuai & 15 & 46,9 & 14 & 43,8 & 29 & 90,6 \\
Meragukan & 1 & 3,1 & 1 & 3,1 & 2 & 6,2 \\
Menyimpang & 0 & 0 & 1 & 3,1 & 1 & 3,1 \\
\hline Jumlah & 16 & 50 & 16 & 50 & 32 & 100 \\
\hline
\end{tabular}


Menurut Soetjiningsih (1995), pertumbuhan dan perkembangan merupakan dua peristiwa yang terjadi secara sinkron pada setiap individu. Tercapainya tumbuh kembang yang optimal tergantung pada potensi biologiknya. Tercapainya potensi biologik seseorang merupakan hasil interaksi beberapa faktor yang saling berkaitan, yaitu faktor genetik, lingkungan-bio-psiko-sosial dan perilaku. Proses yang unik dan hasil akhir yang berbeda-beda yang memberikan ciri tersendiri pada setiap anak.

Menurut Hurlock (1997), seorang anak yang memperoleh perawatan yang memadai, biasanya akan tumbuh dengan cepat dan anak yang kurang memperoleh perawatan kesehatan dan gizi yang memadai, akan mengalami keterlambatan pertumbuhannya.

Menurut peneliti, dari penelitian ini dapat diketahui bahwa tercapainya pertumbuhan yang sesuai didapat dari terpenuhinya perawatan kesehatan dan gizi yang memadai dari ibu yang tidak bekerja yang memiliki lebih banyak waktu bersama dengan anaknya. Selain itu,menurut Soetjiningsih (1995) dapat diketahui bahwa tercapainya pertumbuhan yang optimal dipengaruhi oleh kebutuhan dasar untuk tumbuh kembang yaitu asuh, asah, asih.

Kebutuhan fisik-biomedis (asuh), meliputi pemenuhan kebutuhan pangan atau gizi. Kebutuhan gizi merupakan kebutuhan terpentingpada masa pertumbuhan balita yang erat kaitannya dengan pertumbuhan anak baduta. Kekurangan makanan yang bergizi akan menyebabkan retardasi pertumbuhan baduta. Makanan yang berlebihan juga tidak baik, karena dapat menyebabkan obesitas. Selain itu pemenuhan kebutuhan pokok pada tahap awal perkembangan balita seperti pemberian ASI, imunisasi, pemenuhan sandang, dan kesegaran jasmani rekreasi dapat mempengaruhi proses tumbuh kembang pada anak.

Selain data tentang pertumbuhan dalam penelitian ini juga memaparkan tentang hasil perkembangan dari anak baduta dengan ibu bekerja dan juga perkembangan anak baduta dengan ibu tidak bekerja didapatkan hasil bahwa $93,25 \%$ atau 15 anak baduta dari 16 anak baduta dengan ibu tidak bekerja memiliki pekembangan yang sesuai dengan umurnya sedangkan 1 orang anak baduta dengan ibu tidak bekerja yang berumur 15 bulan memiliki perkembangan yang meragukan, pada KPSP anak tersebut pertanyaan no 6 yaitu apakah anak bisa berdiri selama 30 detik tanpa berpegangan ternyata anak tersebut belum dapat melakukannya, pertanyaan no 7 apakah anak dapat membungkuk untuk mengambil mainanya ternyata anak tersebut belum dapat melakukannya sehingga perkembangan dari anka tersebut meragukan.

Selain itu, $87,5 \%$ atau 14 anak baduta dengan ibu bekerja dari 16 anak baduta memiliki perkembangan yang sesuai $6,25 \%$ atau 1 orang anak baduta berumur 23 bulan pada KPSP pertanyaan no 4 yaitu apakah anak dapat berjalan mundur atau tidak ternyata anak tersebut belum dapat melakukannya, pertanyaan no 6 apakah anak tersebut dapat berjalan naik tangga sendiri ternyata anak tersebut belum dapat melakukkannya sehingga perkembangan anak tersebut meragukan, dan 6,25\% atau 1 anak baduta berumur 6 bulan pada KPSP pertanyaan no 2 apakah anak dapat mempertahankan posisi kepalanya dengan stabil atau belum ternyata anak belum dapat melakukkannya, pertanyaan no 4 apakah bayi dapat telungkup di tempat datar dan dapat menyangga dadanya ternyata anak tersebut belum dapat melakukannya, pertanyaan no 6 pernahkah bayi berbalik sedikitnya $2 \mathrm{x}$ dengan terlentang dan tengkurap ternyata anak tersebut belum dapat melakukannya karena belum bisa tengkurap, pertanyaan no 9 dapatkah bayi meraih mainan yang jauh dari jangkauan tangannya ternyata belum dapat melakkuakan dan pada pertanyaan no 10 apakah bayi dapat mempertahankan lehernya saat kedua jarinya diangkat dengan tangan ternyata bayi tersebut belum dapat melakukan sehingga bayi tersebut memiliki perkembangan menyimpang.

Menurut Soetjiningsih (1995) kebutuhan dasar anak untuk tumbuh kembang, secara umum digolongkan menjadi 3 kebutuhan dasar yaitu Asuh, Asih dan Asah, dari paparan di atas kebutuhan kedua yaitu Asih atau kebutuhan emosi atau kasih sayang yaitu, pada tahun tahun pertama kehidupan, hubungan yang erat mesra dan selaras antara ibu dengan anak merupakan syarat mutlak untuk menjamin tumbuh kembang yang selaras baik fisik, mental maupun psikososial.

Berperannya dan kehadiran ibu sedini dan selanggeng mungkin, akan menjadi rasa aman bagi bayinya. Ini diwujudkan dengan kontak fisik (kulit/ mata) dan pskis sedini mungkin, misalnya dengan menyusu bayi secepat mungkin segera setelah lahir. Kekurangan kasih sayang ibu pada tahun-pertama kehidupan mempunyai dampak negatif pada tumbuh kembang anak baik fisik, mental maupun sosial emosi, yang disebut "Sindrom Deprivasi Mental". 
Kebutuhan tumbuh kembang yang ketiga yaitu asah Stimulasi mental merupakan cikal bakal dan proses belajar (pendidikan dan pelatihan) pada anak. Stimulasi mental (Asah) ini mengembangkan perkembangan mental psikososial: kecerdasan, keterampilan, kemandirian, kreativitas, agama, kepribadian, moral-etika, produktivitas dan sebagainya. Hal ini juga seharusnya dapat didukung dengan keberadaan dari sosok ibu dari anak tersebut sehingga jika kehadiran ibu ataupun tingkat intensitas pertemuan antara anak dengan ibu kurang maka akan didapatkan kemungkinan dari penyimpangan proses perkembangan ataupun pertumbuhan dari anak tersebut.

Menurut peneliti, gangguan perkembangan yang dialami oleh 2 anak baduta dengan ibu bekerja merupakan sebuah fenomena yang dapat disebabkan oleh kurangnya kasih sayang dari seorang ibu dikarenakan ibu yang seharusnya memberikan waktu yang lebih untuk anaknya akan berkurang di karenakan pekerjaan yang dimilikinya sehingga waktu yang digunakan untuk menstimulasi perkembangan pada anak tersebut kurang, atau tidak mendapatkan hasil yang optimal.

Dari hasil penelitian dapat diketahui hampir tidak tampak perbedaan pada pertumbuhan dan perkembangan anak baik dengan ibu yang bekerja maupun tidak bekerja, ini dapat dikarenakan karena ibu yang bekerja tidak semuanya mengabaikan anaknya tetapi ada juga yang memberikan kasih sayang yang baik dan didikan yang baik kepada anaknya sehingga anak tersebut memiliki tumbuh kembang yang sesuai. Dengan demikian dapat dilihat bahwa faktor utama yang mempengaruhi tumbuh kembang anak adalah keseimbangan dalam memenuhi kebutuhan dasar anak (Asuh, Asih, Asah) sangat dibutuhkan untuk mencapai pertumbuhan dan perkembangan yang optimal.

\section{SIMPULAN DAN SARAN}

\section{Simpulan}

Dari hasil penelitian dapat diambil simpulan bahwa tumbuh kembang anak baduta di posyandu se-Kelurahan Bendogerit Kecamatan Sananwetan Kota Blitar pada ibu tidak bekerja lebih baik dari pada tumbuh kembang anak baduta dengan ibu bekerja.

\section{Saran}

Faktor utama yang mempengaruhi tumbuh kembang anak adalah keseimbangan dalam memenuhi kebutuhan dasar anak (Asuh, Asih, Asah) sangat dibutuhkan untuk mencapai pertumbuhan dan perkembangan yang optimal

\section{DAFTAR RUJUKAN}

Hidayat, A. 2005. Pengantar Ilmu Keperawatan Anak. Jakarta: Salemba Medika.

Hurlock, E.B. 1997. Psikologi Perkembangan. Edisi kelima. Jakarta: Erlangga.

Nursalam. 2013. Metodologi Penelitian Ilmu Keperawatan. Jakarta: Salemba Medika.

Soetjiningsih. 1995. Tumbuh Kembang Anak. Jakarta: EGC.

Soetjiningsih. 2001. Tumbuh Kembang Anak. Jakarta: EGC.

Wahyuni. 2014. Dampak Program Bina Keluarga Balita (BKB) Terhadap Tumbuh Kembang Anak Balita (0-24 Bulan). E- jurnal pustaka kesehatan, $\mathrm{Vol} 2$ (no 1) januari 2014.

Wardah, F. 2010. Kapan Sebaiknya Ibu Kembali Bekerja Setelah Melahirkan?. http;//female.Kompas. com/read/2010/09/20/16103380/kapan. sebaiknya. kembali.bekerja.setelah.melahirkan.diakses tanggal 21 september 2014. 